Copyright (C) 2015 by Academic Publishing House Researcher

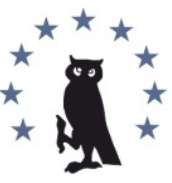

Published in the Russian Federation

European Researcher

Has been issued since 2010 .

ISSN 2219-8229

E-ISSN 2224-0136

Vol. 93, Is. 4, pp. 344-348, 2015

DOI: 10.13187/ er.2015.93.344

www.erjournal.ru

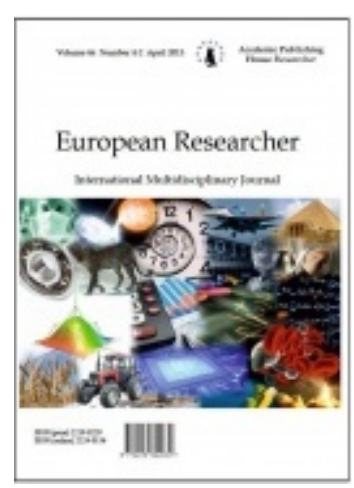

UDC 37.025.3

\title{
Emotional Skills Among Senior High School Age Students in Physical Education Classes
}

\author{
${ }^{1}$ Romualdas K. Malinauskas \\ ${ }^{2}$ Arturas V. Akelaitis
}

\author{
${ }^{1}$ Lithuanian Sports University, Lithuania \\ 6 Sporto street, Kaunas 44221 \\ Dr. (Pedagogy), professor \\ E-mail: romas.malinauskas@lsu.lt \\ 2 Lithuanian Sports University, Lithuania \\ 6 Sporto street, Kaunas 44221 \\ $\mathrm{PhD}$ student \\ E-mail: akelaitisarturas@gmail.com
}

\begin{abstract}
The aim of this study was to analyse and compare the peculiarities of emotional skills among senior high school age students in physical education classes because the significance of emotional intelligence for students is a subject of continuous scientific discussions. The independent random sample consisted of 212 ( 15 - 16 years old) students and 189 (17 - 18 years old) students, of which there were 198 boys and 203 girls. Schutte Self-Report Inventory (SSRI) was employed. This instrument divides emotional skills into four separate components, namely: ability to use personal positive emotional experience, ability to assess and express emotions, ability to understand and analyse emotions and ability to manage emotions. It was found that 17 - 18 years old students have better ability to use own positive emotional experience than those of 15 - 16 years old and girls have better ability to understand and analyse emotions in physical education classes than boys.

Keywords: emotional skills; students; physical education classes; senior high school age.

\section{Introduction}

The significance of emotional intelligence for students is a subject of continuous scientific discussions. The emergence of the emotional intelligence term received a great deal of attention from the scientists and inspired a number of articles. It is a proven fact that the „emotionally gifted" people have inner advantage both in terms of personal and professional life, and therefore they are happier and more successful. It was even suggested that it is the emotional intelligence rather than IQ or cognitive abilities that matters more when predicting and assessing academic and professional achievement [1].

Students with higher emotional skills tend to perform better in school [2], have better quality relationships [3], resolve conflict in more constructive ways [4], solve social reasoning problems more effectively [5], and engage less frequently in unhealthy behaviors [6].
\end{abstract}


In contrast, students with poor emotional skills are more at risk of experiencing learning difficulties and engaging in such behaviours as anti-social behaviour, substance abuse, violence and criminality, and to leave school without any certification or vocational skills, with consequently poor employability opportunities [7, 8, 9].

Physical education classes, where intense emotional situations take place and individuals' characters are tested, are the proper places for the development of students' social and emotional skills $[10,11]$. Physical education classes involve many varied and intense emotions. Student's character and personality can be tested in competitive games, and the positive management of feelings may be governed by a particular ability [12].

Scientific novelty: the present research will provide the first thorough analysis of the components of emotional skills among senior high school age students in physical education classes.

The aim of the research is to analyse and compare the peculiarities of emotional skills among senior high school age students in physical education classes.

\section{Research methods}

Instruments: data colection and analysis. Schutte Self-Report Inventory (SSRI) was employed. This instrument divides emotional skills into four separate components [13], namely: ability to use personal positive emotional experience, ability to assess and express emotions, ability to understand and analyse emotions and ability to manage emotions [14, 15].

The Lithuanian version of the SSRI shows internal consistency value 0.79 and a test-retest reliability coefficient of 0.84 for the overall questionnaire [16]. The statistical hypotheses were tested by applying the Student t-test.

Sample and procedure. The research was carried out during 2013/2014 academic years. According to the earlier research carried out by Mayer, Salovey \& Caruso [17] results that the emotional intelligence also alter with age, senior high school age students were divided into two different age groups. The independent random sample consisted of 212 ( 15 - 16 years old) students and 189 (17 - 18 years old) students, of which there were 198 boys and 203 girls. The survey was conducted in compliance with the ethical principles and applicable legislation, i. e. each respondens was explained the goal of the study and was ensured that the questionnaires were anonymous. The duration of the survey was 20 minutes.

\section{Results}

The research started from the analysis of the ability of 15-16 years old students and 1718 years old students to use personal positive emotional experience in physical education classes. The analysis of the ability to use personal positive emotional experience resulted in the following averages: $50.65 \pm 5.32$ in case of 15- 16 years old students and 51.72 \pm 5.48 in case of 17- 18 years old students. The application of the Student's t-test revealed a statistically significant difference in the ability of 15- 16 years old students to use own positive emotional experience in physical education classes and that of 17- 18 years old students: $t$ (399) $=-1.98 ; \mathrm{p}<0.05$. The obtained results are summarized in table 1 .

Table 1: Mean scores of emotional skills among 15 - 16 years old and 17 - 18 years old students of senior high school age in physical education classes $(\mathrm{M} \pm \mathrm{SD}) *$

\begin{tabular}{|l|c|c|c|}
\hline Emotional skills & $\begin{array}{l}15-16 \text { years } \\
\text { old students } \\
(\mathrm{N}=212)\end{array}$ & $\begin{array}{c}17-18 \text { years } \\
\text { old students } \\
(\mathrm{N}=189)\end{array}$ & $\mathrm{t} ; \mathrm{p}$ \\
\hline $\begin{array}{l}\text { Ability to use personal positive } \\
\text { emotional experience }\end{array}$ & $50.65 \pm 5.32$ & $51.72 \pm 5.48$ & $\mathrm{p}<0.05$ \\
\hline $\begin{array}{l}\text { Ability to assess and express } \\
\text { emotions }\end{array}$ & $21.67 \pm 2.91$ & $21.83 \pm 3.25$ & $\begin{array}{c}-0.52 \\
\mathrm{p}>0.05\end{array}$ \\
\hline
\end{tabular}




\begin{tabular}{|l|c|c|c|}
\hline $\begin{array}{l}\text { Ability to understand and analyze } \\
\text { emotions }\end{array}$ & $31.48 \pm 3.79$ & $32.09 \pm 3.91$ & $\begin{array}{c}-1.58 \\
\mathrm{p}>0.05\end{array}$ \\
\hline Ability to manage emotions & $15.95 \pm 2.84$ & $16.27 \pm 2.96$ & $\begin{array}{c}-1.10 \\
\mathrm{p}>0.05\end{array}$ \\
\hline
\end{tabular}

*Note $(\mathrm{M} \pm \mathrm{SD})$ - mean and standard deviation.

The research also addressed the ability of 15-16 years old students and 17-18 years old students to assess and express emotions in physical education classes. It was determined that 15- 16 years old students and 17- 18 years old students were similar in terms of the ability to assess and express their emotions. The analysis of the ability to assess and express emotions resulted in the following averages: $21.67 \pm 2.91$ in case of $15-16$ years old students and $21.83 \pm 3.25$ in case of 17- 18 years old students, there was no statistically significant difference between 15- 16 years old students and 17- 18 years old students.

The research results revealed that there no significant differences between 15- 16 years old students and 17-18 years old students in terms of their ability to manage emotions and to understand and analyze their emotions in physical education classes $(p>0,05)$.

It was found that girls have a higher ability to understand and analyse emotions in physical education classes than boys: $\mathrm{t}(399)=-1.97 ; \mathrm{p}<0.05$. The analysis of the ability to understand and analyse emotions resulted in the following averages: boys - $31.49 \pm 3.68$ and girls - 32.22 \pm 3.74 . The obtained results are summarized in table 2.

Table 2: Mean scores of emotional skills among boys and girls of senior high school age in physical education classes $(\mathrm{M} \pm \mathrm{SD}) *$

\begin{tabular}{|l|c|c|c|}
\hline Emotional skills & $\begin{array}{c}\text { Boys } \\
(\mathrm{N}=198)\end{array}$ & $\begin{array}{c}\text { Girls } \\
(\mathrm{N}=203)\end{array}$ & $\mathrm{t} ; \mathrm{p}$ \\
\hline $\begin{array}{l}\text { Ability to use personal positive } \\
\text { emotional experience }\end{array}$ & $51.24 \pm 6.04$ & $52,01 \pm 6.28$ & $\begin{array}{c}-1.24 \\
\mathrm{p}>0.05\end{array}$ \\
\hline $\begin{array}{l}\text { Ability to assess and express } \\
\text { emotions }\end{array}$ & $21.63 \pm 3.03$ & $21.87 \pm 3.34$ & $\begin{array}{c}-0.75 \\
\mathrm{p}>0.05\end{array}$ \\
\hline $\begin{array}{l}\text { Ability to understand and } \\
\text { analyze emotions }\end{array}$ & $31.49 \pm 3.68$ & $32.22 \pm 3.74$ & $\begin{array}{c}-1.97 \\
\mathrm{p}<0.05\end{array}$ \\
\hline Ability to manage emotions & $16.01 \pm 3.01$ & $16.22 \pm 3.12$ & $\begin{array}{c}-0.68 \\
\mathrm{p}>0.05\end{array}$ \\
\hline
\end{tabular}

*Note $(\mathrm{M} \pm \mathrm{SD})$ - mean and standard deviation.

\section{Discussion}

The carried out research helped assess the intensity of the components of emotional skills among senior high school age students in physical education classes. The results of this research do not contradict with the results obtained in the earlier research that the emotional intelligence also alter with age [17]. The results of this study showed that 17 - 18 years old students have better ability to use own positive emotional experience in physical education classes than 15 - 16 years old students $(p<0.05)$. As the findings of this research proved that emotional intelligence improves with age and experience, the researcher would agree with Daniel Goleman author of „Working with Emotional Intelligence" that claims the growth of emotional intelligence increases with maturity [18]. Based on research findings provided by the Reuven Bar-On.org, emotional intelligence of older groups usually scored significantly higher than the younger groups and respondents in their late 40s obtained the highest mean scores [19]. 
The results of the present study also revealed that girls have better ability to understand and analyse emotions in physical education classes than boys ( $p<0.05)$. Murphy [20] did not look for senior high school age students but determined that the female respondents had better ability to understand and analyse emotions that the male respondents in that particular research. Emotional intelligence researchers frequently conclude that female respondents score higher than male respondents on emotional intelligence measures [21]. This conclusion is supported by an extensive literature on gender differences in emotional aspects, showing, for example, that female are more capable of decoding nonverbal emotional information [22], have greater emotional understanding [23], are more sensitive to the emotions of others [24], and are more expressive and show greater interpersonal competencies [25].

Emotional skills can be developed in physical education classes via specially designed programs and teaching methods. Therefore, it is worth investigating the relationship between students' social and emotional competencies and skills and other psychological parameters in physical education classes and in other school settings.

\section{Conclusion}

1. The comparison of emotional skills among 15 - 16 years old and 17 - 18 years old students revealed that 17 - 18 years old students have better ability to use own positive emotional experience in physical education classes $(\mathrm{p}<0.05)$.

2. The comparison of emotional skills among boys and girls revealed that girls have better ability to understand and analyse emotions in physical education classes than boys $(p<0.05)$.

\section{References:}

1. Goleman D. Emotional intelligence. New York: Bantam Books, 1995.

2. $\quad$ Rivers S.E., Brackett M.A., Reyes M.R., Mayer J.D., Caruso D.R., Salovey P. Measuring emotional intelligence in early adolescence with the MSCEIT-YV: Psychometric properties and relationship with academic performance and psychosocial functioning // J ournal of Psychoeducational Assessment, 2012. No. 30. P. 344-366.

3. Lopes P.N., Brackett M.A., Nezlek J.B., Schutz A., Sellin I., \& Salovey P. Emotional intelligence and social interaction. // Personality and Social Psychology Bulletin. 2004. No. 30. P. 1018- 1034.

4. $\quad$ Brackett M.A., Rivers S.E., Shiffman S., Lerner N., Salovey P. Relating emotional abilities to social functioning: A comparison of self-report and performance measures of emotional intelligence // J ournal of Personality and Social Psychology. 2006. No. 91. P. 780- 795.

5. Reis D.L., Brackett M.A., Shamosh N.A., Kiehl K.A., Salovey P., \& Gray J. R. Emotional intelligence predicts individual differences in social exchange reasoning // NeuroImage. 2007. No. 35. P. 1385- 1391.

6. $\quad$ Brackett M.A., Mayer J.D., Warner R.M. Emotional intelligence and its relation to everyday behaviour // Personality and Individual Differences. 2004. No. 36. P. 1387- 1402.

7. Adi Y., Killoran A., J anmohamed K., Stewart-Brown S. Systematic review of the effectiveness of interventions to promote mental well-being in primary schools: Universal approaches which do not focus on violence or bullying. London: National Institute for Clinical Excellence, 2007.

8. Colman I., Murray J., Abbott R. A., Maughan B., Kuh D., Croudace T.J ., J ones P.B. Outcomes of conduct problems in adolescence: 40 year follow-up of national cohort // British Medical J ournal. 2009. No. 338. P. 208-211.

9. Bradley R., Doolitte J., Bartolotta R. Building on the data and adding to the discussion: The experiences and outcomes of students with emotional disturbance // J ournal of Behavioral Education. 2008. No. 17. P. 3-23.

10. Tjeerdsma B. Physical education as a social and emotional development laboratory // Teaching Elementary Physical Education. 1999. No. 10. P. 12-16.

11. Laker A. Beyond the boundaries of physical education: educating young people for citizenship and social responsibility. London: Routledge, 2000.

12. Tugade M.M., Fredrickson B.L. Positive emotions and emotional intelligence. In: Barrett L Feldman, Salovey P, eds. The Wisdom of Feelings, New York: Guilford Press, 2001. P. 319-340.

13. Palmer B.R. An analysis of the relationship between various models and measures of emotional inteligence. Doctoral Dissertation. Swinburne University of Technology, 2003.

14. Schutte N.S., Malouff J.M., Hall L. E., Haggerty D. J., Cooper J.T., Golden C.J ., Dornheim L. Development and validation of a measure of emotional intelligence // Personality and Individual Differences, 1998, No. 25. P.167- 177. 
15. Schutte N.S., Malouff J.M. Measuring emotional intelligenceand related constructs. New York: Edwin Mellen Press, 1999.

16. Malinauskas R., Sniras S. Emotional intelligence among future sport pedagogues: results of an empirical study. Science and Processes of Education. 2010. No. 4. P. 81- 88.

17. Mayer J. D., Salovey P., Caruso D. R. Selecting a measure of emotional intelligence. In R. BarOn, \& J.D.A. Parker (Eds.), The handbook of emotional intelligence: Theory, development, assessment, and application at home, school, and in the workplace. San Francisco: J ossey-Bass Inc, 2000. P. 320-342.

18. Goleman D. Working with emotional intelligence. New York: Bantam Books, 1998.

19. Bar-On R. Reuven Bar-On.org: Age differences in EQ-i and EQ-i:YV scores, 2007. Retrieved September 4, 2014, from http:// www.reuvenbaron.org/ bar-on-model/ essay.php?i=24.

20. Murphy A.A comparison of the emotional intelligence and thinking styles of students in different university study fields. Master thesis. J ohannesburg: University of South Africa, 2006.

21. Van Rooy D.L., Dilchert S., Viswesvaran C., Ones D.S. Multiplying intelligences: Are general, emotional, and practical intelligences equal? In K. R. Murphy (Ed.), A critique of emotional intelligence. Mahwah, NJ : Erlbaum, 2006. P. 235-262.

22. Brody L.R., Hall J.A. Gender, emotion, and expression. In M. Lewis, \& J. M. Haviland (Eds.), Handbook of emotions. New York: Guilford, 2000. P. 338-349.

23. Ciarrochi J.V., Hynes K., Crittenden N. Can men do better if they try harder? Sex and motivational effects on emotional awareness // Cognition and Emotion. 2005. No.19. P. 133-141.

24. Hall J .A., Mast M.S. Are women always more interpersonally sensitive than men? Impact of goals and content domain // Personality and Social Psychology Bulletin. 2008. No. 34. P. 144-155.

25. Hargie O., Saunders C., Dickson O. Social skills in interpersonal communication. London: Routledge, 1995.

УДК $37.025 \cdot 3$

\title{
Эмоциональные навыки учащихся старшего школьного возраста на уроках физкультуры
}

${ }_{1}^{1}$ Ромуальдас Казимерович Малинаускас

${ }^{2}$ Артурас Валдович Акялайтис

\author{
1 Литовский университет спорта, Литва \\ 44221 г. Каунас, ул. Спорто, 6 \\ Доктор педагогических наук, профессор \\ E-mail: romas.malinauskas@lsu.lt \\ 2 Литовский университет спорта, Литва \\ 44221 г. Каунас, ул. Спорто, 6 \\ Соискатель \\ E-mail: akelaitisarturas@gmail.com
}

Аннотация. В статье рассматривается эмоциональные навыки учащихся старшего школьного возраста на уроках физкультуры. Независимая случайная выборка учащихся старшего школьного возраста включала 401 респондента: 212 учащихся 15-16 лет и 189 учащихся 17-18 лет, из которых было 198 парней и 203 девушки. Для решения поставленных задач был использован опросник эмоциональной компетентности Н. Шутте с соавт. SSRI, направлен на измерение четырех показателей эмоциональных навыков: способности эмоционального содействия мышлению; понимания и анализа эмоций; идентификации эмоций; управления эмоциями. Установлено, что учащиеся 17-18 лет имеют лучшую способность использовать эмоциональное содействие мышлению, чем учащиеся 15-16 лет, а девушки имеют лучшую способность понимать и анализировать эмоции на уроках физкультуры, чем парни.

Ключевые слова: эмоциональные навыки; учащиеся; уроки физкультуры; старший школьный возраст. 